\title{
Implementasi Akuntansi Sosial Terhadap Corporate Social Responsibility (CSR) Di PT. Tunas Baru Lampung, Tbk. Banyuasin
}

\author{
Septi Minarsih ${ }^{1}$, Totok Sudiyanto ${ }^{2}$, Panca Satria Putra ${ }^{3}$ \\ ${ }^{1}$ Fakultas Ekonomi dan Bisnis Universitas PGRI Palembang, Septiminarsih3@gmail.com \\ ${ }^{2}$ Fakultas Ekonomi dan Bisnis Universitas PGRI Palembang, totoktajir1978@gmail.com \\ ${ }^{3}$ Fakultas Ekonomi dan Bisnis Universitas PGRI Palembang, Ppancasatria@gmail.com
}

\begin{abstract}
The population of this study is the Corporate Social Responsibility report issued by PT. Tunas Baru Lampung, Tbk. Banyuasin. The sample used is the Corporate Social Responsibility (CSR) report issued by PT. Tunas Baru Lampung, Tbk. Banyuasin from 2017, 2018 and 2019. The research method uses qualitative methods which are carried out by collecting, collecting and clarifying data in accordance with actual events. Based on the results of the research expected of companies that have implemented a Social Accounting Implementation program on Corporate Social Responsibility (CSR) at PT. Tunas Baru Lampung, Tbk. Banyuasin 2017 - 2019. The company has also made a good social accounting report on the Corporate Social Responsibility in the partnership and Community Development program, only there is nothing between the partnership program and community development. Suggestions for companies, further approved by the company or approved in the partnership program report to the community, because the community represents one of the work partners of the company and asks the company to always provide opportunities for sons and purti regions to obtain better information and jobs and utilize local resources that are better already available
\end{abstract}

Keywords: Social accounting, Corporate social responsibility (CSR)

\begin{abstract}
ABSTRAK
Populasi penelitian ini adalah laporan Corporate Social Responsibility yang dikeluarkan oleh PT. Tunas Baru Lampung, Tbk. Banyuasin. Sampel yang digunakan adalah laporan Corporate Social Responsibility (CSR) yang dikeluarkan oleh PT. Tunas Baru Lampung,Tbk. banyuasin dari tahun 2017, 2018 dan 2019. Metode penelitian menggunakan metode kualitatif yaitu metode yang dilakukan dengan cara mengumpulkan, menafsirkan dan mengklarifikasi data sesuai dengan kejadian yang sebenarnya. Berdasarkan hasil dari penelitian diketahui bahwa perusahaan telah melaksanakan program Implementasi Akuntansi Sosial Terhadap Corporate Social Responsibility (CSR) di PT. Tunas Baru Lampung, Tbk. Banyuasin 2017-2019. Perusahaan juga telah membuat laporan akuntansi sosal terhadap Corporate Social Responsibility dalam program kemitraan dan bina lingkungan dengan baik, hanya saja tidak ada pemisahan antara program kemitraan dan bina lingkungan. Saran untuk perusahaan, sebaiknya perusahaan lebih terbuka atau transparansi dalam laporan program kemitraan kepada masyarakat, karena masyarakat merupakan salah satu patner kerja perusahaa dan sebaiknya perusahaan selalu memberikan peluang bagi putra dan purti daerah untuk medapatkan penghasilan dan pekerjaan yang lebih baik dan memanfaatkan potensi lokal yang sudah ada.
\end{abstract}

Kata kunci : Akuntansi sosial, Corporate Social Responsibility (CSR)

\section{A. PENDAHULUAN}

Akuntansi sosial merupakan bidang ilmu akuntansi yang saat ini sedang berkembang pesat seiring dengan perkembangan zaman, hal ini di karenakan adanya kesadaran perusahaan terhadap kepentingan lain, selain untuk memaksimumkan laba perusahaan. Perusahaan juga menyadari bahwa mereka selalu bersinggungan dengan berbagai masalah sosial sehingga perusahaan mulai memperhatikan hubungan dengan lingkungan sosial. 
Akuntansi sosial tidak hanya diterapkan dalam badan usaha milik negara, namun juga diterapkan dalam perusahaan swasta. Akuntansi sosial dalam bentuk tanggung jawab sosial atau Corporate Social Responsibility (CSR) merupakan program yang harus diimplementasikan dalam suatu perusahaan, diharapkan dapat meningkatkan partisipasi perusahaan untuk memberdayakan potensi dan kondisi ekonomi, sosial dan lingkungan masyarakat sekitar perusahaan.

Di Indonesia akuntansi sosial telah diatur dalam Undang-undang No. 40 tentang perseroan terbatas (UUPT) yang isinya mewajibkan perusahaan melakukan program Corporate Social Responsibility (CSR) dan mengungkapkan informasinya dalam laporan tahunan perusahaan, kewajiban tersebut tertuang dalam pasal 66 dan 74.

Perusahaan menggunakan akuntansi sosial untuk menyediakan laporan keuangan pertanggung jawaban sosial perusahaan, sebagai salah satu pelaku ekonomi tentunya perusahaan mempunyai peranan yang sangat penting terhadap kelangsungan hidup perekonomian dalam masyarakat luas. Seiring dengan perkembangan suatu perusahaan dalam bidang informasi dan tekhnologi serta adanya keterbukaan pasar menjadikan perusahaan yang ada harus memperhatikan secara serius mengenai dampak yang ditimbulkan perusahaan itu sendiri terhadap lingkungan dan sosialnya. Tidak dipungkiri bahwa sektor industri atau perusahaan yang berskala besar telah mampu memberikan kontribusi terhadap pertumbuhan ekonomi nasional, namun ekploitasi terhadap sumber daya alam yang dilakukan oleh perusahaan semakin besar dan menyebabkan terjadinya degredasi lingkungan yang cukup mengkhawatirkan.

Dengan adanya Corporate Social Responsibility (CSR) perusahaan dapat meningkatkan kegiatan dalam bentuk kepedulian terhadap masyarakat dan lingkungan untuk memperbaiki citra positif perusahaan terhadap dampak negatif yang ditimbulkan. Karena besarnya dampak yang ditimbulkan terhadap kehidupan masyarakat, maka dari itu masyarakat menginginkan dampak ini dapat dikontrol dengan baik. Dimana dampak dari keberadaan perusahaan terhadap keadaan sosial masyarakat dan lingkungan juga merupakan biaya-biaya sosial yang bisa menunjukan kontribusi perusahaan kepada masyarakat. Oleh karena itu, setiap perusahaan wajib membentuk unit kerja khusus yang menangani langsung masalah pembinaan dan pemberdayaan masyarakat dalam mengalokasikan dana pertanggung jawaban sosial perusahaan.

Melalui RUU tanggung jawab sosial yang dibahas, kewajiban program Corporate Social Responsibility (CSR) akan dibebankan ke semua perusahaan dan besarnya dana CSR pun akan ditentukan sebesar dua sampai tiga persen dari laba bersih, menurut wakil ketua komisi VIII DPR Abdul Malik Haramain dikutip dari Kompas.com. Program Corporate Social Responsibility (CSR) di Indonesia selama ini sudah ada, namun masih belum maksimal dari sisi akuntabilitas dan tidak transparan mengenai laporan keuangan laba bersih perusahaan. Ada juga perusahaan yang tidak melaksanakan program CSR namun tetap melapor sudah melaksanakan program tersebut. Maka dari itu, program Corporate Social Responsibility (CSR) perlu adanya pengawasan dari pihak pemerintah.

Sebagai program perusahaan Corporate Social Responsibility (CSR) harus dijalankan secara berkesinambungan dan tidak sesaat untuk menjaga dan berkontribusi dalam pembangunan berkelanjutan dalam rangka untuk meningkatkan kualitas kehidupan masyarakat sekitar perusahaan. Tujuan akhir dari Corporate 
Social Responsibility (CSR) adalah perubahan tidak hanya dirasakan dalam aspek ekonomi saja, namun juga dirasakan dalam aspek sosial dan lingkungan.

Peneliti memilih PT. Tunas Baru Lampung, Tbk. Banyuasin sebagai objek penelitian karena perusahaan ini merupakan salah satu perusahaan swasta, bergerak di bidang perkebunan kelapa sawit dan berbentuk perseroan terbatas yang memiliki komitmen sebagai bentuk tanggung jawab untuk kepentingan lingkungan dan operasional perusahaan terhadap pengelolaan dan pengembangan perkebunan dan fasilitasnya.

Model tanggung jawab sosial perusahaan yang dilakukan PT. Tunas Baru Lampung, Tbk. Banyuasin mencakup tanggungjawab atas dampak kegiatan karyawan, lingkungan, konsumen, pemangku kegiatan, dan masyarakat sekitar.

\section{B. KAJIAN TEORI}

\section{Pengertian Akuntansi Sosial}

D. Crowther (2011:59) mendefinisikan akuntansi sosial sebagai suatu proses mengkomunikasikan dampak sosial dan tindakan ekonomi organisasi untuk kepentingan kelompok tertentu dalam masyarakat dan untuk masyarakat luas. Akuntansi sosial umumnya digunakan dalam konteks bisnis, atau tanggung jawab sosial perusahaan Corporate Social Responsibility (CSR) meskipun setiap organisasi, termasuk lembaga swadaya masyarakat, lembaga amal dan lembaga pemerintahan dapat terlibat dalam akuntansi sosial.

Para pakar akuntansi membuat istilah masing-masing untuk menggambarkan transaksi antara perusahaan dengan lingkungannya, diantaranya:

IAI (2016:10), mendefinisikan bahwa akuntansi sosial juga dikenal sebagai akuntansi lingkungan, pelaporan sosial perusahaan atau akuntansi keberlanjutan atau proses mengkomunikasikan dampak sosial dan lingkungan dari tindakan ekonomi organisasi untuk kepentingan kelompok tertentu dalam masyarakat.

Belkaoui (2011:349), mengemukakan akuntansi sosial sebagai proses pemilihan variabel - variabel, ukuran, dan prosedur pengukuran dari kinerja sosial tingkat perusahaan, yang secara sistematis mengembangkan informasi yang berguna untuk pengevaluasian kinerja sosial perusahaan dan mengkomunikan informasi seperti itu kepada kelompok-kelompok sosial yang berkepentingan, baik didalam maupun diluar perusahaan.

\section{Pengertian Corporate Social Responsibility (CSR)}

Secara etimologis definisi Corporate Social Responsibility (CSR) di Indonesia diterjemaahkan sebagai tanggung jawab sosial dan lingkungan. Namun, Corporate Social Responsibility (CSR) di Indonesia telah diatur dalam undang-undang No. 40 tahun 2007 tentang perseroan terbatas, bahwa sebagaimana yang termuat dalam pasal 1 ayat 3 yang berbunyi tanggung jawab sosial dan lingkungan adalah komitmen perseroan untuk berperan serta dalam pembangunan ekonomi berkelanjutan guna meningkatkan kualitas kehidupan dan kualitas lingkungan yang bermanfaat, baik bagi perseroan itu sendiri, komunitas setempat maupun masyarakat sekitar.

Corporate Social Responsibility (CSR) adalah tanggung jawab perusahaan kepada para pemangku kepentingan untuk berlaku etis, meminimalkan dampak negatif dan memaksimalkan dampak positif yang mencakup aspek ekonomi, sosial dan lingkungan dalam rangka mencapai tujuan pembangunan berkelanjutan (Wibisono, 2016:8). 
Corporate Social Responsibility (CSR) merupakan komitmen perusahaan untuk menyalurkan kontribusi jangka panjang terhadap issue tertentu di masyarakat dan lingkungan agar dapat menciptakan lingkungan yang lebih baik. Kontribusi dari perusahaan ini dapat berupa bantuan tenaga ahli dari perusahaan, bantuan berupa uang, barang dan lainnya. (Ardila, 2017:12).

Dapat disimpulkan bahwa Corporate Social Responsibility (CSR) merupakan kegiatan yang dilakukan oleh perusahaan dalam bentuk pertanggung jawaban sosial kepada sosial dan lingkungan sekitar perusahaan guna untuk menciptakan image atau citra perusahaan yang baik dimata masyarakat.

\section{Teori-Teori Corporate Social Responsibility (CSR)}

Oliver laas (2010), mengemukakan 5 landasan yang menempatkan Corporate Social Responsibility (CSR) sebagai strategi bisnis, yaitu:

1) Strategi Bersaing

Strategi yang menempatkan CSR sebagai keunikan bisnis untuk memenangkan persaingan, karena perusahaan yang melakukan CSR memiliki kelebihan yang berkaitan dengan tanggung jawabnya dalam pengelolaan bisnis yang bukan hanya mengejar keuntungan ekonomi, namun juga senantiasa mentaati hukum dan peraturan yang berlak, juga selalu mengedepankan etika dan senantiasa peduli dengan masalah-masalah sosial yang sedang dihadapi oleh masyarakat sekitar.

2) Strategi Pengelolaan Sumber Daya Alam

Strategi yang tidak hanya memiliki makna pelestarian sumber daya hayati, tetapi juga mencegah kerusakan sumber daya alam yang mengakibatkan bencana, tetapi juga pelestarian sumber daya yang dibutuhkan bagi keberlanjutan bisnis.

3) Strategi Memuaskan Stakeholder

Merupakan praktik bisnis yang terus menerus menjaga kepuasan dan loyalitas pelanggan internal dan pelanggan eksternal yang berkelanjutan, yang berdampak pada peningkatan aksebilitas dalam memperoleh permodalan, pemasaran prodak, dan kebijakan untuk memperoleh dukungan politik dari pemerintah dan masyarakat.

4) Strategi Mengatasi isu dan Krisis

Oleh pelaku bisnis dapat digunakan sebagai alat untuk memperoleh dukungan dari para pemangku kepentingan dalam menghadapi isu-isu negatif yang merugikan, seperti isu kualitas produk melalui terbangunnya citra perusahaan.

5) Strategi Manajemen Lingkungan dan Penilaian Dampak

Manajemen lingkungan akan berdampak pada terjaminnya pasokan bahan baku dan energi, kenaikan keuntungan dari penghematan biaya produksi, dan terhindarnya ancaman bencana atau kerusakan sumber daya alam. Penilaian dampak akan menjaga atau mencegah terjadinya isu-isu dan krisis kepercayaan dari stakeholder.

\section{Konsep-Konsep Corporate Social Responsibility (CSR)}

Menurut Wibisono (2016:32-36) secara konseptual, manfaat tanggung jawab sosial perusahaan merupakan bentuk kepedulian perusahaan yang didasari tiga konsep yang dikenal dengan triple botton line, yaitu profit, people, dan planet.

1) Profit (keuntungan)

Profit merupakan unsur terpenting dalam menjadi tujuan utama dari setiap kegiatan usaha. Tak heran bila fokus utama dari seluruh kegiatan dala perusahaan adalah mengejar profit atau mendongkrak harga saham setinggi-tingginya, baik 
secara langsung maupun tidak langsung. Inilah bentuk tanggung jawab ekonomi yang paling esensi terhadap pemegang saham.

2) People (Masyarakat Pemangku Kepentingan)

Menyadari bahwa masyarakat merupakan Stakeholder penting bagi perusahaan, karena dukungan mereka, sangat diperlukan bagi keberadaan, kelangsungan hidup, dan perkenbangan perusahaan, maka sebagai bagian yang tak terpisahkan dengan masyarakat lingkungan, perusahaan perlu berkomitmen untuk berupaya memberikan manfaat sebesar-besarnya kepada mereka. Selain itu, juga perlu di sadari bahwa operasi perusahaan berpotensi memberikan dampak kepada masyarakat. Karenanya pula perusahaan perlu untuk melakukan berbagai kegiatan yang menyentuh kebutuhan masyarakat.

\section{3) Planet (Lingkungan)}

Jika perusahaan ingin eksis dan akseptabel maka harus di sertakan pula tanggung jawab pada lingkungan. Lingkungan adalah sesuatu yang terkait dengan seluruh bidang kehidupan kita. Semua kegiatan yang kita lakukan mulai dari bagun tidur di pagi hari hingga kita terlelap di malam hari berhubungan dengan lingkungan. Air yang kita minum, udara yang kita hirup, seluruh peralatan yang kita gunakan, semuanya berasal dari lingkungan. Lingkungan bisa menjadi teman atau musuh kita, tergantung bagaimana kita memperlakukannya.

Menurut Carrol (2011) CSR dalam bentuk kepedulian perusahaan terhadap masyarakat sekitar, meliputi beberapa aspek ekonomi, hukum, etika serta kontribusi pada isu sosial. Dari konsep tersebut menunjukan bahwa setiap perusahaan dalam setiap kegiataan CSR harus melihat beberapa aspek karena dari beberapa aspek yang di jelaskan memberikan konrtibusi untuk lingkungan.

\section{Penelitian Terdahulu}

TABEL PENELITIAN TERDAHULU

\begin{tabular}{|c|c|c|c|c|c|}
\hline No & $\begin{array}{c}\text { Nama } \\
\text { Peneliti }\end{array}$ & $\begin{array}{c}\text { Judul } \\
\text { Penelitian }\end{array}$ & Persamaan & Perbedaan & Hasil Penelitian \\
\hline 1 & $\begin{array}{l}\text { Ardila } \\
(2017)\end{array}$ & $\begin{array}{l}\text { Penerapan } \\
\text { Akuntansi Sosial } \\
\text { dalam Program } \\
\text { Kemitraan dan } \\
\text { Bina lingkungan } \\
\text { pada PT. } \\
\text { Rumpun Enam } \\
\text { Bersaudara } \\
\text { Kecamatan } \\
\text { Sungai Rotan } \\
\text { Kabupaten } \\
\text { Muara Enim }\end{array}$ & $\begin{array}{l}\text { Variabelnya } \\
\text { akuntansi } \\
\text { sosial atau } \\
\text { akuntansi } \\
\text { pertanggungj } \\
\text { awaban } \\
\text { sosial. }\end{array}$ & $\begin{array}{l}\text { Pada objek } \\
\text { penelitian } \\
\text { pada } \\
\text { PT.Rumpun } \\
\text { Enam } \\
\text { Bersaudara } \\
\text { Kecamatan } \\
\text { Sungai Rotan } \\
\text { Kabupaten } \\
\text { Muara Enim. } \\
\text { Tahun: } 2014 \text {, } \\
\text { 2015, } 2016\end{array}$ & $\begin{array}{l}\text { Program Tanggung jawab } \\
\text { sosial pada PT. Rumpun } \\
\text { Enam Bersaudara kepada } \\
\text { masyarakat kecamatan sungi } \\
\text { rotan kabupaten muara enim } \\
\text { selama tahun } 2014 \text { sampai } \\
2015 \text { berjumlah } R P, 2.502, \\
130,436 \text {. Untuk dana } \\
\text { sumbangan sarana atau } \\
\text { prasarana umum, kesehatan } \\
\text { masyarakat, pendidikan atau } \\
\text { pelatihan dan sarana ibadah. }\end{array}$ \\
\hline 2 & $\begin{array}{l}\text { Riska Anis } \\
\text { Fatmawani } \\
\text { ngsih } \\
(2016)\end{array}$ & $\begin{array}{l}\text { Pelaksanaan } \\
\text { Corporate } \\
\text { Social } \\
\text { responsibility di } \\
\text { PT. Madubaru } \\
\text { (PG PS } \\
\text { Madukismo) }\end{array}$ & $\begin{array}{l}\text { Variabelnya } \\
\text { akuntansi } \\
\text { pertanggungj } \\
\text { awaban } \\
\text { sosial }\end{array}$ & $\begin{array}{l}\text { Objek } \\
\text { penelitian di } \\
\text { PT. Madubaru } \\
\text { (PG PS } \\
\text { Madukismo) }\end{array}$ & $\begin{array}{l}\text { PT. Madubaru (PG PS } \\
\text { Madukismo) untuk program } \\
\text { bina lingkungan sebesar } \\
0,5 \% \text { dan untuk program } \\
\text { kemitraan sebesar } 0,5 \% \text {. } \\
\text { Transparansi laporan } \\
\text { kegiatan CSR setiap } 3 \text { bulan } \\
\text { sekali, namun monitoring }\end{array}$ \\
\hline
\end{tabular}




\begin{tabular}{|c|c|c|c|c|c|}
\hline & & & & & $\begin{array}{l}\text { yang dilaksanakan belum } \\
\text { maksimal. }\end{array}$ \\
\hline 3 & $\begin{array}{l}\text { Khairunisak } \\
\text { afriani sirait } \\
(2016)\end{array}$ & $\begin{array}{l}\text { Implementasi } \\
\text { Corporate } \\
\text { Social } \\
\text { Responsiblity } \\
\text { pada } \\
\text { Perusahaan PT. } \\
\text { Anglo Eastern } \\
\text { Plantations }\end{array}$ & $\begin{array}{l}\text { Terletak di } \\
\text { variabelnya } \\
\text { (akuntansi } \\
\text { pertanggung } \\
\text { jawaban } \\
\text { sosial atau } \\
\text { CSR) }\end{array}$ & $\begin{array}{l}\text { Ada pada } \\
\text { objek penelitia } \\
\text { pada PT. } \\
\text { Anglo Eastern } \\
\text { Plantations } \\
\text { kota Medan, } \\
\text { Sumatera } \\
\text { Utara } \\
\text { Tahun: } 2014 \text {, } \\
2015,2016\end{array}$ & $\begin{array}{l}\text { PT. Anglo Eastern } \\
\text { Plantations telah } \\
\text { melaksanakn program CSR } \\
\text { setiap tahunnya dengan } \\
\text { perencanaan dan } \\
\text { implementasi yang jelas, } \\
\text { program tersebut adalah } \\
\text { pendidikan, kesehatan, } \\
\text { pembangunan sarana dan } \\
\text { prasarana,sosial,budaya dan } \\
\text { agama serta pemberdayaan } \\
\text { tenaga kerja. Hanya dari segi } \\
\text { transparansi dan } \\
\text { akuntabilitas masih belum } \\
\text { maksimal }\end{array}$ \\
\hline
\end{tabular}

\section{METODE PENELITIAN}

a. Objek/Lokasi Penelitian

Penelitian ini dilakukan di PT. Tunas Baru Lampung,Tbk.Banyuasin. Dimana perusahaan ini berbentuk perseroan terbatas yang bergerak dibidang kelapa sawit, berlokasi di desa Sidomulyo, kecamatan Air Kumbang, kabupaten Banyuasin.

b. Metode Penelitian

Sugiono (2014:2), metode penelitian di artikan sebagai cara ilmiah untuk mendapatkan data dengan tujuan dan keuangan tertentu, cara ilmiah berarti kegiatan penelitian itu didasarkan pada ciri-ciri keilmuan, yaitu rasional, empiris, dan sistematis. Metode penelitian yang di gunakan oleh peneliti adalah metode kualitatif yaitu metode yang dilakukan dengan cara mengumpulkan, menafsirkan dan mengklarifikasi data sesuai dengan kejadian yang sebenarnya.

\section{c. Variabel Penelitian}

Arikunto (2014:161), variabel merupakan objek penelitian, atau apa yang menjadi titik perhatian suatu penelitian. Dalam penelitian ini penulis menggunakan variabel penelitian yaitu Implementasi Akuntansi Sosial terhadap Corporate Social Responsibility (CSR) di PT. Tunas Baru Lampung, Tbk. Banyuasin.

d. Populasi

Arikunto (2014:173), populasi merupakan objek penelitian dari segi keseluruhan. Populasi dalam penelitian ini adalah laporan Corporate Social Responsibility yang dikeluarkan oleh PT. Tunas Baru Lampung, Tbk. Banyuasin.

\section{e. Sampel}

Arikunto (2014:174), sampel merupakan sebagian atau wakil populasi yang akan diteliti. Jika peneliti hanya akan meneliti sebagian dari populasi, maka peneliti tersebut adalah penelitian sampel. Sampel yang digunakan dalam penelitian ini adalah laporan Corporate Social Responsibility (CSR) yang dikeluarkan oleh PT. Tunas Baru Lampung,Tbk. Banyuasin dari tahun 2017 sampai 2019.

\section{f. Teknik Pengumpulan Data}

Arikunto (2014:193) berpendapat bahwa Teknik pengumpulan data adalah alat bantu yang dipilih oleh penulis dalam mengumpulkan informasi atau data. Teknik pengumpulan data dalam penelitian ini, yaitu: 


\section{g. Wawancara}

Wawancara atau kuisioner lisan adalah sebuah dialog yang dilakukan oleh pewawancara untuk memperoleh informasi dari terwawancara.

Dalam penelitian ini wawancara dilakukan dengan karyawan PT. Tunas Baru Lampung,Tbk. banyuasin yang mengurus Corporate Social Responsibility (CSR).

d. Dokumentasi

Dalam penelitian ini dokumentasi yang didapatkan berupa catatan atau laporan historis, transkip, agenda dan lain sebagainya yang berkaitan atau berhubungan dengan penyaluran dana Corporate Social Responsibility (CSR).

e. Teknik Analisis Data

Sugiono (2014:428) adalah proses mencari dan menyusun secara sistematis data yang diperoleh dari hasil wawancara dan dokumentasi. Penelitian ini menggunakan metode analisis deskriptif kualitatif, yaitu data-data kualitatif yang telah diklarifikasikan dan dianalisi sehingga dapat memberikan gambaran dan keterangan yang lengkap tentang masalah yang dihadapi dalam penelitian ini. Teknik yang dilakukan yaitu penulis mengumpulkan teori-teori dari berbagai sumber dan literatur, kemudian teori-teori tersebut dikaitkan dengan penerapan yang sudah dilakukan perusahaan. Peneliti menganalisis laporan yang telah dibuat oleh perusahaan, dimana analisis tersebut berdasarkan akuntansi pertanggung jawaban sosial. Setelah laporan tersebut dianalisis, maka dapat diklarifikasi sejauh mana penerapan akuntansi sosial pada PT. Tunas Baru Lampung, Tbk. Banyuasin.

\section{HASIL PENELITIAN DAN PEMBAHASAN}

1) Hasil Penelitian

Berikut ini data laporan Corporate Social Responsibility (CSR) dari tahun 2017, 2018 dan 2019. Total jumlah dana bantuan yang dikeluarkan oleh PT.Tunas Baru Lampung, Tbk. Banyuasin Rp. 308.557.650.

\section{TABEL DANA CORPORATE SOCIAL RESPONSIBILITY (CSR) PT. TUNAS BARU LAMPUNG, TBK. BANYUASIN \\ TAHUN 2017, 2018, 2019}

(Dalam Rupiah)

\begin{tabular}{|c|r|r|c|}
\hline Sektor Bantuan & \multicolumn{1}{|c|}{$\mathbf{2 0 1 7}$} & \multicolumn{1}{c|}{$\mathbf{2 0 1 8}$} & \multicolumn{1}{|c|}{$\mathbf{2 0 1 9}$} \\
\hline Bantuan sumbangan & 36.715 .000 & 43.500 .000 & 32.000 .000 \\
\hline Sarana dan prasarana umum & 23.357 .400 & 10.500 .000 & 14.700 .000 \\
\hline Kesehatan masyarakat & 1000.000 & 4.700 .000 & 2.000 .000 \\
\hline Pendidikan dan pelatihan & 14.500 .000 & 7.500 .000 & 33.500 .000 \\
\hline Keagamaan & 21.206 .250 & 35.100 .000 & 2.500 .000 \\
\hline Kemitraan & 8.500 .000 & 12.329 .000 & 11.950 .000 \\
\hline Jumlah & 105.278 .650 & 113.629 .000 & 96.650 .000 \\
\hline
\end{tabular}




\section{Sumber: Isfo PT. Tunas Baru Lampung, Tbk. Banyuasin.}

Dari laporan diatas dapat diketahui bahwa pada tahun 2017 perusahaan mengeluarkan dana yang berkaitan dengan masyarakat yaitu bantuan berupa sumbangan sebesar Rp. 36.715.000, dana sarana dan prasarana umum sebesar Rp. 23.357.400, dana kesehatan masyarakat Rp. 1.000.000, dana pendidikan dan pelatihan sebesar Rp. 14.500.000, dana keagamaan Rp. 21.206.250, dana kemitraan Rp. 8.500.000. Jadi, total jumlah dana keseluruhan yang dikeluarkan oleh perusahaan sebesar Rp. 105.278.650. pada tahun 2018 perusahaan mengeluarkan dana yang berkaitan dengan masyarakat mengalami kenaikan yaitu bantuan berupa sumbangan sebesar Rp. 43.500.000, dana sarana dan prasarana umum sebesar Rp. 43.500.000, dana kesehatan masyarakat menjadi Rp. 4.700.000, dana pendidikan dan pelatihan Rp. 7.500.000, dana keagamaan sebesar Rp. 7.500.000, dana kemitraan sebesar Rp. 12.329.000. Jadi, total jumlah dana keseluruhan yang dikeluarkan oleh perusahaan sebesar Rp. 113.629.000. Sedangkan pada tahun 2019 perusahaan mengeluarkan dana yang berkaitan dengan masyarakat mengalami penurunan yaitu bantuan berupa sumbangan menjadi Rp. 32.000.000, dana sarana dan prasarana umum menjadi Rp. 14.700.000, dana kesehatan masyarakat Rp. 2.000.000, namun dana pendidikan dan pelatihan mengalami kenaikan menjadi $\mathrm{Rp}$. 33.500.000, dana keagamaan mengalami penurunan Rp. 2.500.000, dana kemitraan Rp. 11.950.000. Jadi, total jumlah dana keseluruhan yang dikeluarkan oleh perusahaan sebesar Rp. 96.650.000.

\section{2) Pembahasan}

$>$ Sektor Bantuan Sumbangan

Tahun 2017 sebesar Rp. 36.715.000, kemudian pada tahun 2018 sebesar Rp. 43.500.000, berarti ada kenaikan 18,40\%, dengan nominal Rp. 6.785.000, sedangkan pada tahun 2019 dana sumbangan yang dikeluarkan sebesar Rp. 32.000.000, berarti ada penurunan dari tahun 2018 dan 2019 sebesar 26,74\% dengan nominal Rp. -11.500.000. Tahun 2017 dan 2019 mengalami penurunan sebesar $14,73 \%$, dengan nominal Rp. -4.715 .000 .

$>\quad$ Sektor Sarana dan Prasarana Umum

Tahun 2017 sebesar Rp. 23.357.000, kemudian pada tahun 2018 sebesar Rp. 10.500.000, berarti ada penurunan 55\%, dengan nominal Rp. -12.857.400, sedangkan pada tahun 2019 sebesar Rp. 14.700.000, berarti ada kenaikan dari tahun 2018 dan 2019 sebesar 4\% dengan nominal Rp. 4.200.000. Tahun 2017 dan 2019 mengalami penurunan sebesar 37,6\% dengan nominal Rp. -8.657.400.

\section{$>\quad$ Sektor Kesehatan Masyarakat}

Tahun 2017 sebesar Rp. 1.000.000, kemudian pada tahun 2018 sebesar Rp. 4.700.000, berarti ada kenaikan 3,7\%, dengan nominal Rp. 3.700.000, sedangkan pada tahun 2019 sebesar Rp. 2.000.000, berarti ada penurunan dari tahun 2018 dan 2019 sebesar 57,44\% dengan nominal Rp. -2.700.000. Tahun 2017 dan 2019 mengalami kenaikan sebesar 1\% dengan nominal Rp. 1.000.000.

$>\quad$ Sektor Pendidikan dan Pelatihan

Tahun 2017 sebesar Rp. 14.500.000, kemudian pada tahun 2018 sebesar Rp. 7.500.000, berarti ada penurunan 48,27\%, dengan nominal Rp. -7.000.000, sedangkan pada tahun 2019 sebesar Rp. 33.500.000, berarti ada kenaikan dari 
tahun 2018 dan 2019 sebesar 34,66\% dengan nominal Rp. 26.000.000. Tahun 2017 dan 2019 mengalami kenaikan sebesar 1,31\% dengan nominal Rp. 19.000.000.

\section{$>$ Sektor Keagamaan}

Tahun 2017 sebesar Rp. 21.206.250, kemudian pada tahun 2018 sebesar Rp. 35.100.000, berarti ada kenaikan 65,51\%, dengan nominal Rp. 13.893.750, sedangkan pada tahun 2019 sebesar Rp. 2.500.000, berarti ada penurunan 92,87\% dari tahun 2018 dan 2019 dengan nominal Rp. -32.600.000. tahun 2017 dan 2019 mengalami penurunan sebesar $88,21 \%$ dengan nominal Rp. -18.706.250.

\section{$>$ Sektor kemitraan}

Tahun 2017 sebesar Rp. 8.500.000, kemudian pada tahun 2018 sebesar Rp. 12.329.000, berarti ada kenaikan 45,4\%, dengan nominal Rp. 3.829.000, sedangkan pada tahun 2019 dana yang dikeluarkan sebesar Rp. 11.950.000, berarti ada penurunan dari tahun 2018 dan 2019 sebesar 3,74\% dengan nominal Rp.-379.000. Tahun 2017 dan 2019 mengalami kenaikan sebesar 40,58\%, dengan nominal Rp. 3.450.000.

\section{$>\quad$ Jumlah Dana Corporate Social Responsibility (CSR)}

Tahun 2017 sebesar Rp. 105.278.650, kemudian pada tahun 2018 sebesar Rp. 113.629.000, berarti ada kenaikan 7,93\%, dengan nominal Rp. 8.350.350, sedangkan pada tahun 2019 sebesar Rp. 96.650.000, berarti ada penurunan dari tahun 2018 dan 2019 sebesar 14,94\% dengan nominal Rp. -16.979.000. Tahun 2017 dan 2019 mengalami penurunan sebesar 8,19\% dengan nominal Rp. -8.628.650.

Berdasarkan analisis di atas, bahwa besar kecilnya pemberian dana CSR adalah berdasarkan permintaan kebutuhan lingkungan yang disampaikan oleh masyarakat sekitar perusahaan, sementara besar kecilnya pencairan dana berdasarkan keputusan kantor pusat.

\section{$>\quad$ Laporan Sosial PT. Tunas Baru Lampung, Tbk. Banyuasin}

PT. Tunas Baru Lampung, Tbk. Banyuasin telah mengeluarkan dana bina lingkungan dan kemitraan dalam bentuk pengungkapan dari pelaksanaan tanggung jawab sosial secara nyata.

Sejauh ini dana yang dikeluarkan oleh PT. Tunas Baru Lampung, Tbk. Banyuasin lebih didasarkan pada perusahaan sebagai bagian dari masyarakat untuk berpartisipasi aktif dalam upaya meningkatkan kualitas hidup masyarakat sekitar perusahaan, pegawai perusahaan dan lingkungan perusahaan secara keseluruhan sesuai dengan misi yang diemban oleh PT. Tunas Baru Lampung, Tbk. Banyuasin.

Dana sosial yang dikeluarkan oleh PT. Tunas Baru Lampung, Tbk. Banyuasin sehubungan dengan pelaksanaan tanggung jawab sosial perusahaan, sebagai wujud kepedulian perusahaan kepada masyarakat sekitar perusahaan. Dana untuk masyarakat sekitar ini antara lain:

\section{$\checkmark$ Dana sumbangan}

Dana sumbangan ini berupa sumbangan untuk kegiatan yang dilakukan masyarakat contohnya, lomba untuk masyarakat sekitar, acara kegiatan desa dan kegiatan masyarakat lainnya.

Dana sarana dan prasarana umum

Dana sarana dan prasarana umum ini berupa dana perbaikan jalan, perbaikan balai desa, biaya perbaikan tanah pemakaman umum (TPU), perbaikan 
insfrastruktur, pemberian perabot desa, kapolsek, kecamatan berupa kursi, meja dan perlengkapan lainnya.

$\checkmark \quad$ Kesehatan masyarakat

Dana kesehatan masyarakat yang dilakukan oleh perusahaan berupa dana bantuan dana di posyandu, pemeriksaan kesehatan masyarakat dan bantuan dana kegiatan - kegiatan lainnya yang berhubungan dengan masyarakat.

$\checkmark \quad$ Pendidikan dan pelatihan

Dana pendidikan dan pelatihan ini berupa bantuan beasiswa ke sekolah sekolah, dana bantuan kegiatan kuliah kerja nyata $(\mathrm{KKN})$, dana bantuan karang taruna dan bantuan - bantuan lainnya yang berhubungan dengan pendidikan dan pelatihan.

$\checkmark \quad$ Keagamaan

Dana keagamaan ini berupa bantuan kegiatan tabliq akbar, bantuan kegiatan pengajian, bantuan hari besar keagamaan dan bantuan - bantuan lainnya yang berhubungan dengan keagamaan.

$\checkmark$ Kemitraan

Dana kemitraan ini merupakan dana untuk mempertahankan kerjasama dengan stakeholder, bantuan modal, bantuan pelantikan, bantuan pembuatan banner, dan bantuan kegiatannya yang berhubungan dengan kemitraan.

Implementasi konsep-konsep CSR PT. Tunas Baru Lampung, Tbk. Banyuasin

Pendiri PT. Tunas Baru Lampung telah meletakkan dasar yang sangat kokoh bagi keberlanjutan bisnis yaitu pereseroan, mitra kerja dan pelanggan. Para pendiri PT. Tunas Baru Lampung meyakini bahwa hanya dengan adanya manfaat bersama antar ketiga pihak tersebut, maka bisnis perseroan akan berjalan secara keberlanjutan.

Perusahaan juga menerapkan empat landasan yang meliputi: people, Planet Product, dan profit.

People.

PT. Tunas Baru Lampung berkomitmen penuh pada peningkatan kualitas kehidupan masyarakat disekitar lokasi operasional. Termasuk didalamnya para pekerja, petani plasma, dan masyarakat yang terkenal dampak operasi. Khusus kepada para petani plasma perusahaan berupaya untuk mengembangkan kemampuan dan pengetahuan teknis mereka guna menuju pada penerapan praktik terbaik industri perkebunan yang berkelanjutan.

Planet

PT. Tunas Baru Lampung berkomitmen untuk berkontribusi pada pencapaian tujuan pembangunan berkelanjutan antara lain dengan berupaya untuk sepenuhnya mengadopsi prinsip-prinsip dan kriteria yang tertuang di dalam Indonesia Sustainable Palm Oil (ISPO). PT. Tunas Baru Lampung berkomitmen agar seluruh anak perusahaan kami mendapat sertifikasi ISPO, terlebih lagi karena ISPO merupakan kewajiban bagi perusahaan perkebunan kelapa sawit Indonesia untuk beroperasi secara ramah lingkungan dan ramah sosial.

Product

PT. Tunas Baru Lampung berkomitmen untuk memproduksi minyak kelapa sawit dari kebun yang dikelola dengan prinsip yang ramah lingkungan. Selain memperhatikan adopsi aneka kemajuan teknologi untuk memacu produktivitas 
dan kualitas, aspek jaminan kesehatan dan pengelolaan tanggung jawab lingkungan, tetap merupakan prioritas utama.

Profit

Kunci sukses pencapaian profit perseroan adalah integritas dan keseimbangan antara kepentingan people, planet, dan Product. PT. Tunas Baru Lampung memutuskan bahwa strategi terbaik untuk menyeimbangkan ketiganya hingga berdampak pada perolehan keuntungan adalah dengan menegakkan standar tertinggi prinsip-prinsip tata kelola perusahaan yang baik, mengimplementasikan secara penuh prinsip-prinsip keterbukaan, akuntabilitas, tanggung jawab, kemandirian, dan kewajaran.

\section{E. KESIMPULAN DAN SARAN}

1) Kesimpulan

Berdasarkan analisis dan pembahasan pada bab sebelumnya, maka penulis mengambil kesimpulan dimana hasil menunjukan bahwa perusahaan mengeluarkan dana dalam laporan CSR PT. Tunas Baru Lampung, Tbk. Banyuasin berupa dana bantuan sumbangan, sarana dan prasarana umum, kesehatan masyarakat, pendidikan dan pelatihan, keagamaan, dan kemitraan.

Pada tahun 2017 jumlah dana bantuan yang dikeluarkan oleh perusahaan dalam laporan CSR sebesar Rp. 105.278.650. Namun pada tahun 2018 jumlah dana bantuan yang dikeluarkan oleh perusahaan dalam laporan CSR mengalami kenaikan menjadi Rp. 113.629.000, disebabkan banyaknya permintaan bantuan sumbangan yang harus di penuhi. Sedangkan pada tahun 2019 jumlah dana bantuan yang dikeluarkan oleh perusahaan dalam laporan CSR mengalami penurunan, dengan jumlah dana Rp. 96.650.000, disebabkan berkuranganya permintaan bantuan sumbangan dan keagamaan.

Total dana bantuan secara keseluruhan yang di keluarkan perusahaan dalam laporan CSR tahun 2017, 2018 dan 2019 mengalami fruktuasi, baik itu dalam bantuan sumbangan, sarana dan prasarana umum, kesehatan masyarakat, pendidikan/pelatihan, keagamaan dan kemitraan sebesar Rp. 315.557.650.

\section{2) Saran}

Berdasarkan kesimpulan diatas peneliti mencoba untuk memberikan saran yang mungkin dapat berguna bagi perusahaan PT. Tunas Baru Lampung, Tbk. Banyuasin dalam implementasikan akuntansi sosial terhadap corporate social responcibility.

Perusahaan harus lebih efektif mengenai anggaran dan realisasi program CSR, serta lebih terbuka atau transparansi dalam laporan program kemitraan kepada masyarakat, karena masyarakat merupakan salah satu patner kerja perusahaan, Perusahaan juga harus selalu memberikan peluang bagi putra dan purti daerah untuk medapatkan penghasilan dan pekerjaan yang lebih baik dan memanfaatkan potensi lokal yang sudah ada dan pemerintah harus lebih mengontrol perusahaan dalam mencakup corporate Social Responsibility (CSR) dan mengajak serta dan membina masyarakat dalam menuju kemakmuran dan kesejahteraan bersama. 


\section{DAFTAR PUSTAKA}

Ardila. 2017. Penerapan Akuntansi Sosial dalam Program Kemitraan dan Bina Lingkungan di PT. Rumpun Enam Bersaudara Kecamatan Sungai Rotan Kabupaten Muara Enim. Muara Enim: Universitas PGRI Palembang.

Arikunto, Suharsimi. 2014. Prosedur Penelitian. Jakarta: Rineka Cipta.

Carrol, 2011. The Pyramid of Corporate Social Responsibility: Toward The Moral Management Of Organization Stakeholder. (online).

Fatmawaningsih, Anis Rizka. 2016. Pelaksanaan Corporate Social Responsibility di PT. Madubaru (PG PS Madukismo). (online). Yogyakarta: Universitas Negeri Yogyakarta.

Sirait, Afrini Khairunnisak, 2018. Implementasi Corporate social responsibility pada PT. Anglo Estern Plantation (online) Medan: Universitas Islam Negeri Sumatera Utara.

Sugiono. 2014. Metode Penelitian Bisnis. Bandung: Alfabet.

Wibisono, Yusuf. 2016. Membedah Konsep dan Aplikasi CSR. Gresik: Fascho Publishing. 